\title{
Early Season Growth, Yield, and Fruit Quality of Standard and Mini Watermelon Grafted onto Several Commercially Available Cucurbit Rootstocks
}

\author{
Matthew B. Bertucci ${ }^{1,6}$, Katherine M. Jennings ${ }^{2}$, David W. Monks ${ }^{2}$, \\ Jonathan R. Schultheis ${ }^{2}$, Penelope Perkins-Veazie ${ }^{2}$, Frank J. Louws ${ }^{3,4}$, \\ and David L. Jordan ${ }^{5}$
}

AdDitional INDEX wORDs. Citrullus lanatus, Cucurbita maxima, Cucurbita moschata, Cucurbita pepo, Lagenaria siceraria, scion

SUMMARY. Grafting watermelon (Citrullus lanatus) is a common practice in many parts of the world and has recently received increased interest in the United States. The present study was designed to evaluate early season growth, yield, and fruit quality of watermelon in response to grafting and in the absence of known disease pressure in a fumigated system. Field experiments were conducted using standard and mini watermelons (cv. Exclamation and Extazy, respectively) grafted onto 20 commercially available cucurbit rootstocks representing four species: giant pumpkin (Cucurbita maxima), summer squash (Cucurbita pepo), bottle gourd (Lagenaria siceraria), and interspecific hybrid squash [ISH (C. maxima $\times$ Cucurbita moschata)]. Nongrafted 'Exclamation' and 'Extazy' were included as controls. To determine early season growth, leaf area was measured at 1, 2, and 3 weeks after transplant (WAT). At 1 WAT, nongrafted 'Exclamation' produced the smallest leaf area; however, at $3 \mathrm{WAT}$, nongrafted 'Exclamation' produced the largest leaf area in 2015 , and no differences were observed in 2016. Leaf area was very similar among rootstocks in the 'Extazy' study, with minimal differences observed. Marketable yield included fruit weighing $\geq 9$ and $\geq 3$ lb for 'Exclamation' and 'Extazy', respectively. In the 'Exclamation' study, highest marketable yields were observed in nongrafted 'Exclamation', and 'Exclamation' grafted to 'Pelops', 'TZ148', and 'Coloso', and lowest marketable yields were observed when using 'Marvel' and 'Kazako' rootstocks, which produced $47 \%$ and $32 \%$ of nongrafted 'Exclamation' yield, respectively. In the 'Extazy' study, the highest marketable yield was observed in nongrafted 'Extazy', and 'Kazako' produced the lowest yields (48\% of nongrafted 'Extazy'). Fruit quality was determined by measuring fruit acidity ( $\mathrm{pH})$, soluble solids concentration (SSC), lycopene content, and flesh firmness from a sample of two fruit from each plot from the initial two harvests of each year. Across both studies, rootstock had no effect on SSC or lycopene content. As reported in previous studies, flesh firmness was increased as a result of grafting, and nongrafted 'Exclamation' and 'Extazy' had the lowest flesh firmness among standard and mini watermelons, respectively. The present study evaluated two scions with a selection of 20 cucurbit rootstocks and observed no benefits in early season growth, yield, or phytonutrient content. Only three of 20 rootstocks in each study produced marketable yields similar to the nongrafted treatments, and no grafted treatment produced higher yields than nongrafted 'Exclamation' or 'Extazy'. Because grafted seedlings have an associated increase in cost and do not produce increased yields, grafting in these optimized farming systems and using fumigated soils does not offer an advantage in the absence of soilborne pathogens or other stressors that interfere with watermelon production.

G rafting watermelon is a common practice in many parts of the world, including China, Korea, Japan, Spain, Italy, and Israel, but has yet to be adopted widely in the United States (Kubota et al., 2008; Sakata et al., 2007). Reported benefits of grafting include resistance to diseases caused by soilborne pathogens, abiotic stress tolerance, and enhanced yield and fruit quality (Davis et al., 2008b; Lee and Oda, 2003; Louws et al., 2010). Modern vegetable grafting was first introduced in watermelon production in 1920, when Japanese growers grafted watermelon to squash rootstocks to provide resistance to fusarium wilt (Fusarium oxysporum f. sp. niveum) and other soilborne pests (Lee and Oda, 2003; Tateishi, 1927). In Turkey, higher yields were reported in grafted watermelon compared with nongrafted watermelon, although grafted watermelon exhibited a decrease in fruit quality (Turhan et al., 2012). In Japan and Korea, watermelon production has undergone an intensification on limited arable acreage, and many growers use permanent high tunnel structures or greenhouses for production. Permanent structures restrict the ability for crop rotation, which led to the adoption of grafting to address diseases incited by soilborne pathogens (Kubota et al., 2008; Lee and Oda, 2003; Sakata et al., 2007).

Vegetable grafting became an important pest management option following the removal of methyl bromide as a soil fumigant (Zagheni, 2003 ). The loss of methyl bromide and the success of grafting in Asian countries have caused an increased interest in vegetable grafting in western regions including Europe, North Africa, the Middle East, and Central and South America (Kubota et al., 2008; Miguel et al., 2004; Moreno et al., 2016). A study in Egypt reported only $67 \%$ survival of nongrafted watermelon that were planted in a fusarium wilt-infested field, whereas grafted plants had $83 \%$ to $100 \%$ survival and a corresponding increase in yield (Mohamed et al., 2012). In Spain and South America, economic analyses support the use of grafting where growers observe high levels of fusarium wilt in fields (Miguel et al., 2004; Moreno et al., 2016).

Despite reported benefits of grafting, U.S. watermelon growers are slow to adopt the practice because of the associated increases in labor costs, seed costs, greenhouse space, and management time required to oversee the grafting process (Kubota et al., 2008). If grafted seedlings are purchased, growers can expect to pay $\$ 0.75-\$ 1.00$ per seedling compared with $\$ 0.28$ per nongrafted seedling, so grafting must provide substantial benefits to offset the expense (Taylor et al., 2008 ). Research in Oklahoma demonstrates that if a grower expects high yields $\left(50,000 \mathrm{~kg} \cdot \mathrm{ha}^{-1}\right)$, grafted watermelon fruit would have to sell for $\$ 0.22 / \mathrm{kg}$ to break even compared with a price of $\$ 0.15 / \mathrm{kg}$ for nongrafted watermelon fruit (Taylor et al., 2008). Furthermore, researchers in Oklahoma emphasize the importance of the history of the field being 
considered for watermelon production. If a field is historically free of fusarium wilt and disease is not anticipated to become a problem, a grower would benefit by avoiding the increased cost associated with grafted seedlings (Taylor et al., 2008). In Washington, researchers developed cost estimate analyses that favor the implementation of grafting for growers in the Pacific northwestern United States. The results were based on a series of assumptions, particularly an increase in yield of grafted plants and the effectiveness of grafting as an alternative to fumigation for disease control (Galinato et al., 2016). However, the authors note that growers should review the assumptions to check whether the expenses and yields in the models match those of the grower.

Several studies report no difference or even reduced yields in grafted watermelon as compared with nongrafted watermelon, particularly in the absence of disease pressure (Bertucci et al., 2017; Kokalis-Burelle et al., 2016). Under disease-free conditions in Florida, grafted watermelon yielded nearly $50 \%$ less total fruit weight than nongrafted watermelon (Kokalis-Burelle et al., 2016). Yields from seeded watermelon scions grafted to bottle gourd rootstocks were increased and yields were decreased when grafting to ISH rootstocks (Yetisir et al., 2003). This disparity emphasizes the need for

This material was supported by the National Institute of Food and Agriculture, U.S. Department of Agriculture, under award number 2011-01397.

We would like to thank Chris Lee and the staff of the Cunningham Research Station for their efforts to maintain these field sites. We would like to thank Brad Thompson, Keith Starke, David Suchoff, Sushila Chaudhari, Nick Basinger, Shawn Beam, Sam McGowen, Cole Smith, and Matthew Waldschmidt for their help in executing the studies. We would like to thank the USDA-NIFA-2011-51181-30963 for providing funding for this research and also thank NC State University and NC Department of Agriculture and Consumer Services for supporting this research. Finally, we are grateful for the watermelon and rootstock seeds which were generously donated by each company.

${ }^{1}$ Department of Crop, Soil, and Environmental Sciences, University of Arkansas, Fayetteville, AR 72701

${ }^{2}$ Department of Horticultural Science, North Carolina State University, Raleigh, NC 27695

${ }^{3}$ Department of Entomology and Plant Pathology, North Carolina State University, Raleigh, NC 27695

${ }^{4}$ NSF Center for Integrated Pest Management, North Carolina State University, Raleigh, NC 27695

${ }^{5}$ Department of Crop and Soil Sciences, North Carolina State University, Raleigh, NC 27695

${ }^{6}$ Corresponding author. E-mail: bertucci@uark.edu.

https://doi.org/10.21273/HORTTECH04051-18 further investigation of yield response to grafting watermelon in the southeastern United States.

It is important that grafted plants are tested and evaluated in the environment where they will be grown. Rootstock performance is dependent on edaphic factors and climatic conditions, which will define how each rootstock performs in a given environment (Kumar et al., 2017). Thus, one of the major difficulties of grafting is finding the appropriate rootstock-scion combination. The objectives of this study were to graft both standard and mini watermelons (cultivars Exclamation and Extazy, respectively) on 20 commercially available rootstocks to determine the effect of grafting on early season growth, time to maturity, fruit yield, and fruit quality of standard and mini watermelons in the southeastern United States.

\section{Materials and methods}

Field studies were conducted in separate fields in 2015 and 2016 at the Cunningham Research Station (lat. $35.297^{\circ} \mathrm{N}$, long. $78.275^{\circ} \mathrm{W}$ ) in Kinston, NC. Soil at this site was Norfolk loamy sand (fine-loamy, kaolinitic, thermic Typic Kandiudults) with $\mathrm{pH} 5.8$ and 6.7 , and $1.2 \%$ and $1.6 \%$ organic matter in 2015 and 2016 , respectively.

Scions for the experiment were the two triploid (seedless) watermelon cultivars: Exclamation (Syngenta Seeds, Greensboro, NC), an oblong, standardsized watermelon and Extazy (Hazera Seeds Ltd., Berurim, Israel), a round mini watermelon. 'Exclamation' and 'Extazy' were selected based on availability to North Carolina growers and to evaluate the utility of grafting for both standard and mini watermelons. Scions were grafted onto one of 20 commercially available rootstocks representing four species: giant pumpkin, summer squash, bottle gourd, and ISH rootstocks (Table 1 ). Nongrafted 'Exclamation' or 'Extazy' were included as control treatments. Rootstocks were selected based on previous literature or personal communication that indicated a potential benefit for watermelon production. An up-to-date list of cucurbit rootstock options for growers is available online (Kleinhenz, 2015).

SEEDLING PRODUCTION. Rootstock and scion seeds were sown in 72-cell planting trays (T.O. Plastics, Clearwater, MN) filled with soilless propagation media (CC Tobacco Mix; Carolina Soil Co., Kinston, NC). Twenty-four hours before sowing, planting trays were filled with propagation media, watered thoroughly, brought into a greenhouse adjusted to $84^{\circ} \mathrm{F}$, and placed on heating pads set to $89^{\circ} \mathrm{F}$. Seeds of triploid watermelon were oriented with the radicle oriented upward to facilitate release of the seed coat (Maynard, 1989). After seeds were sown, planting trays were placed on heating pads and covered with clear polyethylene film overnight for insulation. During daylight, polyethylene was removed and seedling trays were watered overhead as needed to keep substrate moist. On seedling emergence, heating pads were removed from beneath trays and polyethylene was no longer used to cover trays. When rootstock cotyledons had fully opened and the apical meristem was first exposed, rootstocks were treated with $25 \mu \mathrm{L}$ of a $6.25 \%$ dilution of fatty alcohol solution (Fair 85; Fair Products, Cary, $\mathrm{NC)}$ to prevent regrowth of the

\begin{tabular}{llll}
\hline $\begin{array}{l}\text { Units } \\
\text { To convert U.S. to SI, } \\
\text { multiply by }\end{array}$ & U.S. unit & SI unit & $\begin{array}{l}\text { To convert SI to U.S., } \\
\text { multiply by }\end{array}$ \\
\hline 0.4047 & $\mathrm{acre}(\mathrm{s})$ & $\mathrm{ha}$ & $2.471 \mathrm{l}$ \\
29,574 & $\mathrm{fl} \mathrm{oz}$ & $\mu \mathrm{L}$ & $3.3814 \times 10^{-5}$ \\
29.5735 & $\mathrm{fl} \mathrm{oz}$ & $\mathrm{mL}$ & 0.0338 \\
0.3048 & $\mathrm{ft}$ & $\mathrm{m}$ & 3.2808 \\
2.54 & inch(es) & $\mathrm{cm}$ & 0.3937 \\
25.4 & inch $(\mathrm{es})$ & $\mathrm{mm}$ & 0.0394 \\
6.4516 & inch & $\mathrm{cm}^{2}$ & 0.1550 \\
0.4536 & $\mathrm{lb}$ & $\mathrm{kg}$ & 2.2046 \\
1.1209 & $\mathrm{lb} / \mathrm{acre}$ & $\mathrm{kg} \cdot \mathrm{ha}^{-1}$ & 0.8922 \\
4.4482 & $\mathrm{lbf}$ & $\mathrm{N}$ & 0.2248 \\
28.3495 & $\mathrm{Oz}$ & $\mathrm{g}$ & 0.0353 \\
1 & $\mathrm{ppm}$ & $\mu \mathrm{gg} \cdot \mathrm{g}^{-1}$ & 1 \\
$\left({ }^{\circ} \mathrm{F}-32\right) \div 1.8$ & ${ }^{\circ} \mathrm{F}$ & ${ }^{\circ} \mathrm{C}$ & $\left({ }^{\circ} \mathrm{C} \times 1.8\right)+32$ \\
& & &
\end{tabular}


Table 1. Comprehensive list of rootstock, scion, and pollinizer cultivars used in replicated field experiments conducted in Kinston, NC, to determine the effect of grafting on early season growth, yield, and fruit quality of grafted and nongrafted standard watermelons and mini watermelons.

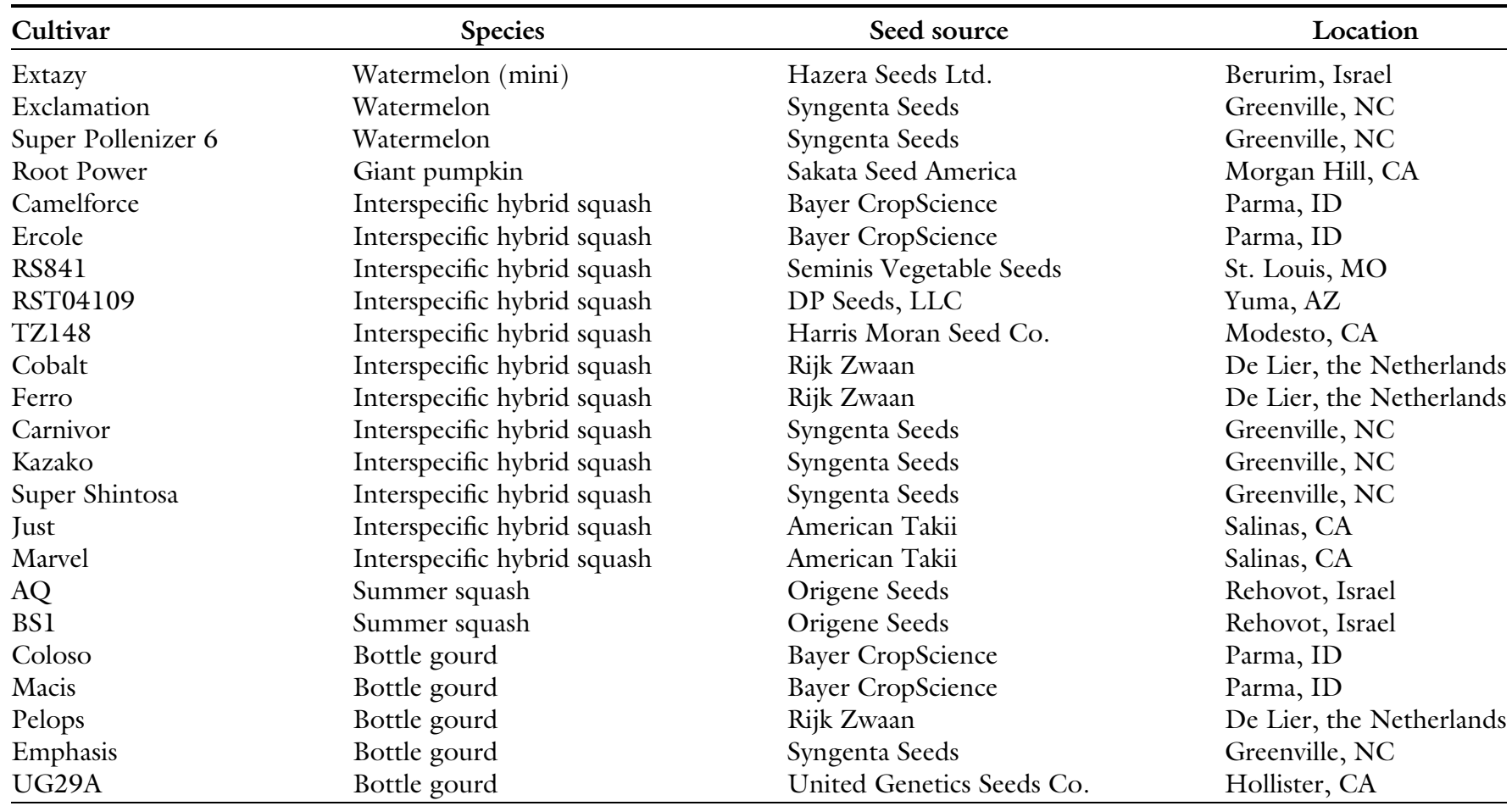

rootstock following grafting, according to methods developed by Daley and Hassell (2014). Preliminary germination tests were conducted using 24 seeds of each rootstock and scion to determine the appropriate dates to sow each cultivar to conduct all grafting in a single operation (data not shown). Seeds for each rootstock were sown at staggered timings over a 4-d span to ensure all could be treated with fatty alcohol within 1-2 $\mathrm{d}$ of each other. Twenty-four hours before grafting, all plants were taken indoors to slow photosynthesis and reduce metabolic activity. Grafting was conducted using the one-cotyledon method (Hassell et al., 2008).

Field SITE PREPARATION. In one operation, beds $(6$ inches high $\times 30$ inches wide) were formed on $10-\mathrm{ft}$ centers, drip tape was laid (3 inches deep), and beds were covered with black polyethylene mulch on 29 Apr. 2015 and 8 Apr. 2016. For soilborne pest control, fumigant (Pic-Clor 60; TriEst Ag Group, Greenville, NC) was applied during bed formation, delivering chloropicrin and 1,3dichloropropene at 174 and 114 $\mathrm{kg} \cdot \mathrm{ha}^{-1}$ a.i., respectively. Watermelon transplanting occurred on 1 June 2015 and 18 May 2016. Planting holes were punched in polyethylene mulch using a tractor-mounted fixed wheel hole puncher (Berry Hill Irrigation, Buffalo Junction, VA) $24 \mathrm{~h}$ before transplanting to allow fumigants, if present, to dissipate. The experimental unit for both watermelon types was a plot with six plants. 'Exclamation' seedlings were transplanted in 15 -ft plots with each seedling transplanted at $2.5-\mathrm{ft}$ in-row spacing on $10-\mathrm{ft}$ centers and $10-\mathrm{ft}$ alleys to separate plots on the same bed. 'Extazy' seedlings were transplanted in 9-ft plots at 1.5 -ft in-row spacing on 10 - $\mathrm{ft}$ centers, with $10-\mathrm{ft}$ alleys. To minimize border effects within plots, competitor seedlings were transplanted on each side of a plot at the same spacing as the triploid plants. In 2015, 'Little Deuce Coup' (Syngenta Seeds) and 'Orange Crisp' (Harris Moran Seed Co., Rochester, NY) were transplanted on the ends of each plot at 2.5- and 1.5 - $\mathrm{ft}$ spacing for 'Exclamation' and 'Extazy' plots, respectively. In 2016, cultivars Palomar and Petite Perfection (Syngenta Seeds) were transplanted as competitor plants for 'Exclamation' and 'Extazy' plots, respectively. Pollenizer seedlings [SP-6 ('Super Pollenizer 6'; Syngenta Seeds)] per plot were transplanted within plots between every second triploid plant, to ensure sufficient pollen production and proper fruit set for the triploid watermelons (Dittmar et al., 2010).

WATERMELON LEAF AREA. To determine early season growth characteristics, leaf area was measured from two triploid plants per plot at 1,2 , and 3 WAT. Leaf area was measured by capturing an overhead image of the two center plants of a plot with a digital SLR camera (Rebel EOS T3; Canon USA, Huntington, NY) from a height of $7 \mathrm{ft}$ above the beds. Images were then analyzed using the Easy Leaf Area software (Easlon and Bloom, 2014). Easy Leaf Area software compared green pixels in an image with contrasting red pixels from a scale of known dimensions ( 3 $\times 3 \mathrm{~cm}$, in this case) and then calculated the total leaf area from the two values. The final leaf area measurement was recorded at $3 \mathrm{WAT}$, which was the last opportunity to record individual watermelon plant growth before substantial canopy overlap.

WATERMELON HARVEST. Watermelons were harvested at weekly intervals when ripe, beginning at 65 and $72 \mathrm{~d}$ after transplanting in 2015 and 2016, respectively. Ripeness was 
determined by scouting for a dried tendril where the fruit meets the vine, a well-developed ground spot where the fruit contacts the soil surface, ridges extending along the rind of the melon, and a breakdown of epicuticular wax and hairs on the fruit surface. Ripeness was more difficult to identify with 'Extazy', so harvest was initiated $10 \mathrm{~d}$ later in 2016 (82 d after transplanting), and fruit were scouted for an additional senescent tendril proximal to the crown from the fruit (Vinson et al., 2010). Fruit of 'Exclamation' were harvested four times in each year, whereas fruit of 'Extazy' were harvested five times and three times in 2015 and 2016, respectively. Marketable yields and marketable fruit counts were summed across all harvests within each year. Standard and mini watermelons were considered marketable if they weighed $\geq 9$ and $\geq 3 \mathrm{lb}$, respectively. Standard watermelons are commonly divided into "bin counts" referring to the number of fruit that would fill one 800-lb watermelon bin. For standard watermelons, watermelon yield and fruit count were categorized in accordance with the National Watermelon Research and Development Group standards: culls $(<9 \mathrm{lb}), 60$-count $(\geq 9-$ $13.5 \mathrm{lb}), 45$-count (>13.5-17.5 lb), 36-count (>17.5-21.5 lb), and 30count (>21.5 lb) (Coolong, 2015). No national standard for grading has been reported for mini watermelons, so fruit weighing $\geq 3 \mathrm{lb}$ were considered marketable, which is similar to previous studies with mini watermelon (Colla et al., 2011; Rouphael et al., 2008).

WATERMELON FRUIT QUALITY. A two-fruit sample from the initial two harvests in each year was tested for flesh firmness, soluble solids content, $\mathrm{pH}$, and lycopene content. Flesh firmness was measured using a digital force gauge (Force One FDIX; Wagner Instruments, Greenwich CT) mounted to a drill press and fitted with a $0.45-\mathrm{mm}$-diameter flat probe. Fruit were prepared for flesh firmness measurements by cutting each fruit longitudinally, from stem to blossom, and ensuring that the cut passed through the ground spot. One half of each fruit was then positioned on a staging platform with a rounded recession to secure the fruit. The force gauge was pressed into the fruit and peak resistance (Newtons) was recorded and averaged for five positions within the fruit: top, bottom, stem, blossom, and heart.

For SSC, pH, and lycopene content, $100-\mathrm{g}$ samples were scooped from the center of each watermelon, bagged individually, and immediately placed on ice. Samples were kept on ice for no longer than $6 \mathrm{~h}$ before storage in a freezer $\left(0^{\circ} \mathrm{F}\right)$ until transport to the Plants for Human Health Institute (Kannapolis, NC) for analysis. Before analysis, samples were thawed and blended for $45 \mathrm{~s}$ until homogenized using a laboratory blender (model 7010S 1L; Waring Commercial, Torrington, CT). Samples were analyzed for SSC and $\mathrm{pH}$ using a digital refractometer (PAL-1; Atago USA, Bellevue WA) and digital pH meter (model H260G; Hach,
Loveland, CO), respectively. Lycopene concentration was determined using 5 - $\mathrm{mL}$ aliquots diluted in $15 \mathrm{~mL}$ deionized water. Sample absorbance at 560 and $700 \mathrm{~nm}$ were measured with a spectrophotometer (UltraScan PRO; HunterLab, Reston, VA). Lycopene content (micrograms per gram fresh weight) was calculated using the following formula: (Abs560-Abs700) $\times$ [dilution factor $(\mathrm{DF})] \times$ slope, where Abs560 and Abs700 are sample absorbance at 560 and $700 \mathrm{~nm}$, respectively; DF is the ratio of sample weight to deionized water; and slope is a calculated correction (28) for the spectrophotometer using an external lycopene standard (Davis et al., 2003).

STATISTICAL ANALYsis. Treatments for both 'Exclamation' and

Table 2. Comparison of the effect of rootstock selection on 'Exclamation' watermelon leaf area using image analysis outputs from Easy Leaf Area software (Easlon and Bloom, 2014) of overhead images captured at a height of $7 \mathrm{ft}(2.1$ $\mathrm{m})$ of two standard watermelon plants at 1, 2, and 3 weeks after transplanting (WAT) from field trials in Kinston, NC, in 2015 and 2016. For all images, a $3 \times$ $3-\mathrm{cm}(1.2 \mathrm{inch})$ red scale was used as a reference to calibrate the Easy Leaf Area software and determine watermelon leaf area.

\begin{tabular}{|c|c|c|c|c|}
\hline \multirow[b]{3}{*}{ Rootstock $^{\mathrm{y}}$} & \multicolumn{4}{|c|}{ Watermelon leaf area $\left(\mathrm{cm}^{2}\right)^{\mathrm{z}}$} \\
\hline & \multirow{2}{*}{$\frac{1 \mathrm{WAT}}{\text { Years combined }}$} & \multirow{2}{*}{$\frac{2 \text { WAT }}{\text { Years combined }}$} & \multicolumn{2}{|c|}{3 WAT } \\
\hline & & & 2015 & 2016 \\
\hline Exclamation-NG & $104 \mathrm{e}^{\mathrm{x}}$ & $1,049 \mathrm{ab}$ & $4,478 \mathrm{a}$ & 3,662 \\
\hline Just & $187 \mathrm{abc}$ & $1,292 \mathrm{ab}$ & $3,855 \mathrm{ab}$ & 3,528 \\
\hline Camelforce & $217 \mathrm{a}$ & $1,649 \mathrm{a}$ & $3,708 \mathrm{ab}$ & 4,335 \\
\hline TZ148 & $185 \mathrm{a}-\mathrm{d}$ & $1,283 \mathrm{ab}$ & $3,471 \mathrm{ab}$ & 3,345 \\
\hline Pelops & $137 \mathrm{~b}-\mathrm{e}$ & $950 \mathrm{~b}$ & $3,265 \mathrm{ab}$ & 2,793 \\
\hline $\mathrm{AQ}$ & $153 \mathrm{a}-\mathrm{e}$ & $1,111 \mathrm{ab}$ & $3,152 \mathrm{ab}$ & 3,342 \\
\hline RS841 & $142 \mathrm{~b}-\mathrm{e}$ & $1,125 \mathrm{ab}$ & $3,088 \mathrm{ab}$ & 3,498 \\
\hline Coloso & $132 \mathrm{~b}-\mathrm{e}$ & $949 \mathrm{~b}$ & $3,077 \mathrm{ab}$ & 3,160 \\
\hline Root Power & $140 \mathrm{~b}-\mathrm{e}$ & $1,000 \mathrm{ab}$ & $3,020 \mathrm{ab}$ & 3,172 \\
\hline Macis & $149 \mathrm{a}-\mathrm{e}$ & $1,080 \mathrm{ab}$ & $3,017 \mathrm{ab}$ & 2,376 \\
\hline Ercole & $156 \mathrm{a}-\mathrm{e}$ & $1,122 \mathrm{ab}$ & $2,850 \mathrm{ab}$ & 3,574 \\
\hline Cobalt & $142 \mathrm{~b}-\mathrm{e}$ & $966 \mathrm{ab}$ & $2,810 \mathrm{ab}$ & 3,103 \\
\hline RST04109 & $137 \mathrm{~b}-\mathrm{e}$ & $1,048 \mathrm{ab}$ & $2,578 \mathrm{ab}$ & 3,547 \\
\hline Marvel & $197 \mathrm{ab}$ & $1,150 \mathrm{ab}$ & $2,176 \mathrm{ab}$ & 3,321 \\
\hline Ferro & $153 \mathrm{a}-\mathrm{e}$ & $972 \mathrm{ab}$ & $2,049 \mathrm{ab}$ & 3,511 \\
\hline BSI & $117 \mathrm{de}$ & $727 \mathrm{~b}$ & $2,042 \mathrm{ab}$ & 2,930 \\
\hline Super Shintosa & $145 \mathrm{a}-\mathrm{e}$ & $913 \mathrm{~b}$ & $1,982 \mathrm{ab}$ & 3,234 \\
\hline Carnivor & $174 \mathrm{a}-\mathrm{d}$ & $1,073 \mathrm{ab}$ & $1,929 \mathrm{ab}$ & 3,642 \\
\hline UG29A & $186 \mathrm{abc}$ & $1,153 \mathrm{ab}$ & $1,903 \mathrm{ab}$ & 4,131 \\
\hline Emphasis & $122 \mathrm{cde}$ & $784 \mathrm{~b}$ & $1,738 \mathrm{~b}$ & 3,128 \\
\hline Kazako & $136 \mathrm{~b}-\mathrm{e}$ & $747 \mathrm{~b}$ & $1,573 \mathrm{~b}$ & 2,126 \\
\hline Effect & & Pvaluew & & \\
\hline Rootstock (R) & $<0.001$ & 0.001 & 0.001 & 0.139 \\
\hline Year $(\mathrm{Y})$ & 0.001 & $<0.001$ & - & - \\
\hline $\mathrm{Y} \times \mathrm{R}$ & 0.238 & 0.477 & & \\
\hline
\end{tabular}

${ }^{\mathrm{z}} 1 \mathrm{~cm}^{2}=0.1550$ inch $^{2}$

'Rootstocks were grafted with 'Exclamation' standard watermelon as the scion. 'Exclamation-NG' represents the nongrafted control.

${ }^{x}$ Means separations achieved using the post hoc Tukey's HSD adjustment for multiple comparisons. Values not followed by letters indicate a lack of significance at the $P=0.05$ level.

${ }^{\text {w}}$ Probability values reported from analysis of variance output using PROC MIXED in SAS (version 9.4; SAS Institute). Rootstock, year, and year $\times$ rootstock had 20,1 , and $20 \mathrm{df}$, respectively. 
'Extazy' studies were arranged in a randomized complete block design with three replications of all treatment combinations in 2015 and four replications in 2016. Analysis of variance (ANOVA) was conducted separately for 'Exclamation' and 'Extazy' studies using PROC MIXED in SAS (version 9.4; SAS Institute, Cary, NC) with year, rootstock, and the interaction of year with rootstock treated as fixed effects, and rep nested within year treated as a random effect. All dependent variables were checked for signs of heteroscedasticity using residual plots output from PROC MIXED. Marketable fruit number, total fruit number, and leaf area required a square root transformation to meet the ANOVA assumptions of normality and homoscedasticity. Following ANOVA and means separation, these data were back-transformed for presentation in tables for ease of interpretation. If no significant interaction of year with rootstock was observed at a 0.05 significance level, then least square means for rootstocks were averaged over years. Means separation was achieved using the post hoc Tukey's honestly significant difference (HSD) adjustment for multiple comparisons with the significance level of $P=0.05$.

\section{Results}

WATERMELON LEAF AREA. Watermelon leaf area at 1, 2, and 3 WAT were recorded separately for 'Exclamation' and 'Extazy' studies. In the 'Exclamation' study, no significant interaction of year with rootstock was observed for leaf area measurements at 1 and 2 WAT; thus, means separation was conducted using combined means across both years. However, a significant interaction of year with rootstock was observed at 3 WAT, and means from 2015 and 2016 are reported separately (Table 2). At I WAT, nongrafted 'Exclamation' had the smallest leaf area and measured only $53 \%$ of 'Marvel' rootstock, which had the largest leaf area at that time. At $2 \mathrm{WAT}$, nongrafted 'Exclamation' had an intermediate leaf area relative to grafted treatments, and it did not differ statistically from 'Camelforce', which exhibited the largest leaf area. At 3 WAT, nongrafted 'Exclamation' produced the largest leaf area in 2015, but it was only statistically different from two rootstocks ('Emphasis' and 'Kazako'). In 2016, no statistical differences were observed in leaf area at 3 WAT.

Analysis of 'Extazy' leaf area detected a significant interaction of year with rootstock at 1 WAT; thus, means from 2015 and 2016 are reported separately (Table 3 ). At 2 and 3 WAT, no significant interactions of year with rootstock existed; thus, means separation was conducted using combined means across both years. At 1 WAT, no differences in leaf area were observed among rootstocks in 2015 , and little separation was observed in 2016 with 18 of 21 treatments producing leaf area that was not significantly different from any other treatment. No differences were observed in leaf area at 2 WAT. At 3 WAT, 'Kazako' rootstock produced a very small leaf area, only $53 \%$ of the nongrafted 'Extazy'. Means separation of leaf area according to Tukey's HSD indicated that only nongrafted 'Extazy' and 'Kazako' differed from one another at 3 WAT, and all other treatments shared a common statistical group (Table 3 ).

Leaf area measurements at 1 WAT were indicative of initial seedling size rather than the rate of seedling growth. Watermelon seedlings did not have rapid growth between 0 and I WAT; furthermore, the one-cotyledon grafting method

Table 3. Comparison of the effect of rootstock selection on 'Extazy' watermelon leaf area using image analysis outputs from Easy Leaf Area software (Easlon and Bloom, 2014) of overhead images captured at a height of $7 \mathrm{ft}(2.1 \mathrm{~m})$ of two mini watermelon plants at 1,2 , and 3 weeks after transplanting (WAT) from field trials in Kinston, NC, in 2015 and 2016. For all images, a $3 \times 3-\mathrm{cm}(1.2 \mathrm{inch}) \mathrm{red}$ scale was used as a reference to calibrate the Easy Leaf Area software and determine watermelon leaf area.

\begin{tabular}{|c|c|c|c|c|}
\hline \multirow[b]{3}{*}{ Rootstock $^{\mathrm{y}}$} & \multicolumn{4}{|c|}{ Watermelon leaf area $\left(\mathrm{cm}^{2}\right)^{\mathrm{z}}$} \\
\hline & \multicolumn{2}{|c|}{ I WAT } & \multirow{2}{*}{$\frac{2 \text { WAT }}{\text { Years combined }}$} & \multirow{2}{*}{$\frac{3 \mathrm{WAT}}{\text { Years combined }}$} \\
\hline & 2015 & 2016 & & \\
\hline Extazy-NG & 81 & $189 a b^{x}$ & 1,311 & $3,746 \mathrm{a}$ \\
\hline UG29A & 119 & $273 a$ & 1,282 & 3,485 a \\
\hline $\mathrm{AQ}$ & 148 & $173 \mathrm{ab}$ & 1,097 & $3,452 \mathrm{a}$ \\
\hline Camelforce & 125 & $229 \mathrm{ab}$ & 1,177 & $3,415 \mathrm{a}$ \\
\hline Pelops & 101 & $210 \mathrm{ab}$ & 1,026 & 3,389 a \\
\hline Emphasis & 141 & $188 \mathrm{ab}$ & 1,114 & 3,343 a \\
\hline Macis & 134 & $163 \mathrm{~b}$ & 1,063 & $3,329 \mathrm{a}$ \\
\hline Coloso & 112 & $239 \mathrm{ab}$ & 1,153 & $3,308 \mathrm{ab}$ \\
\hline Carnivor & 111 & $202 \mathrm{ab}$ & 1,210 & $3,286 \mathrm{ab}$ \\
\hline BS1 & 127 & $212 \mathrm{ab}$ & 1,212 & $3,272 \mathrm{ab}$ \\
\hline RS841 & 102 & $274 \mathrm{a}$ & 1,073 & $3,175 \mathrm{ab}$ \\
\hline Root Power & 113 & $202 \mathrm{ab}$ & 1,148 & $3,168 \mathrm{ab}$ \\
\hline Ercole & 127 & $211 \mathrm{ab}$ & 1,099 & $3,165 \mathrm{ab}$ \\
\hline Just & 117 & $224 \mathrm{ab}$ & 1,018 & $3,139 \mathrm{ab}$ \\
\hline RST04109 & 112 & $194 \mathrm{ab}$ & 970 & $3,105 \mathrm{ab}$ \\
\hline Cobalt & 105 & $238 \mathrm{ab}$ & 1,003 & $2,958 \mathrm{ab}$ \\
\hline Ferro & 112 & $226 \mathrm{ab}$ & 1,006 & $2,911 \mathrm{ab}$ \\
\hline Super Shintosa & 115 & $210 \mathrm{ab}$ & 939 & $2,909 \mathrm{ab}$ \\
\hline TZ148 & 108 & $201 \mathrm{ab}$ & 997 & $2,483 \mathrm{ab}$ \\
\hline Marvel & 117 & $223 \mathrm{ab}$ & 1,108 & $2,449 \mathrm{ab}$ \\
\hline Kazako & 101 & $213 \mathrm{ab}$ & 791 & $2,012 \mathrm{~b}$ \\
\hline Effect & & & $P$ value ${ }^{\mathrm{w}}$ & \\
\hline Rootstock (R) & 0.331 & 0.005 & 0.261 & 0.003 \\
\hline Year $(\mathrm{Y})$ & - & - & 0.002 & 0.776 \\
\hline $\mathrm{Y} \times \mathrm{R}$ & & & 0.084 & 0.136 \\
\hline
\end{tabular}

${ }^{\mathrm{z}} 1 \mathrm{~cm}^{2}=0.1550$ inch $^{2}$.

'Rootstocks were grafted with 'Extazy' mini watermelons as the scion. 'Extazy-NG' represents the nongrafted control.

${ }^{\mathrm{x}}$ Means separations achieved using the post hoc Tukey's HSD adjustment for multiple comparisons. Values not followed by letters indicate a lack of significance at the $P=0.05$ level

w Probability values reported from analysis of variance output using PROC MIXED in SAS (version 9.4; SAS Institute). Rootstock, year, and year $\times$ rootstock had 20,1 , and $20 \mathrm{df}$, respectively. 
affected initial leaf area due to the large rootstock cotyledons, particularly the ISH rootstocks. The leaf area results suggest that, aside from two poor-performing rootstocks ('Kazako' and 'Emphasis'), grafting does not significantly affect early season growth of watermelon plants, and most treatments produce similar leaf area at the end of the initial 3 WAT.

WATERMELON YIELD AND FRUIT NUMBER. Means separation was conducted according to Tukey's HSD to compare the effects of rootstock on watermelon marketable yield, total yield, marketable fruit number, average marketable fruit size, and overall average fruit size. For most of the yield responses, no significant interaction of year with rootstock was observed, and least square means were averaged across both years (Table 4). However, a significant interaction $(P=0.026)$ of year with rootstock was observed in total yield of 'Extazy' mini watermelon; thus, means were reported separately by year (Table 5 ).

In the standard fruit size ' $\mathrm{Ex}$ clamation' study, nongrafted plants produced the highest marketable yield, total yield, marketable fruit number, total fruit number, and average marketable fruit size (Table 4). 'Exclamation' grafted onto 'Pelops', 'TZ148', and 'Coloso' produced similar marketable yield to nongrafted 'Exlcamation', and the next highest marketable yield was 'Root Power' rootstock which produced only $69 \%$ of the nongrafted 'Exclamation'. The lowest marketable yields were observed when 'Exclamation' was grafted onto 'Marvel' and 'Kazako' rootstocks which produced $47 \%$ and $32 \%$ of nongrafted 'Exclamation', respectively. Rootstock had a relatively small effect on average fruit size andaverage marketable fruit size. Nongrafted 'Exclamation' produced the largest marketable fruit, but the average marketable fruit size was similar to 15 of the remaining 20 rootstocks (Table 4). And the smallest marketable fruit ('Kazako') were $82 \%$ of the nongrafted 'Exclamation' treatment.

To further describe watermelon fruit size distribution, 'Exclamation' watermelons were graded according to bin counts (Coolong, 2015). Because total yield differed between rootstocks, the percentages (by weight) of total yield in each category were reported for each rootstock treatment (Table 6). A significant effect of rootstock was observed for culls, 60 -count, and marketable fruit. With $34 \%$ of its yield graded as culls, 'Kazako' rootstock produced the highest percentage of nonmarketable fruit (and correspondingly, the lowest

Table 4. Comparison of the effect of rootstock selection on yield parameters of 'Exclamation' standard watermelon in Kinston, NC, in 2015 and 2016. Ripe fruit were harvested four times each season at weekly intervals, weighed individually, and then summed within each year to determine yield parameters.

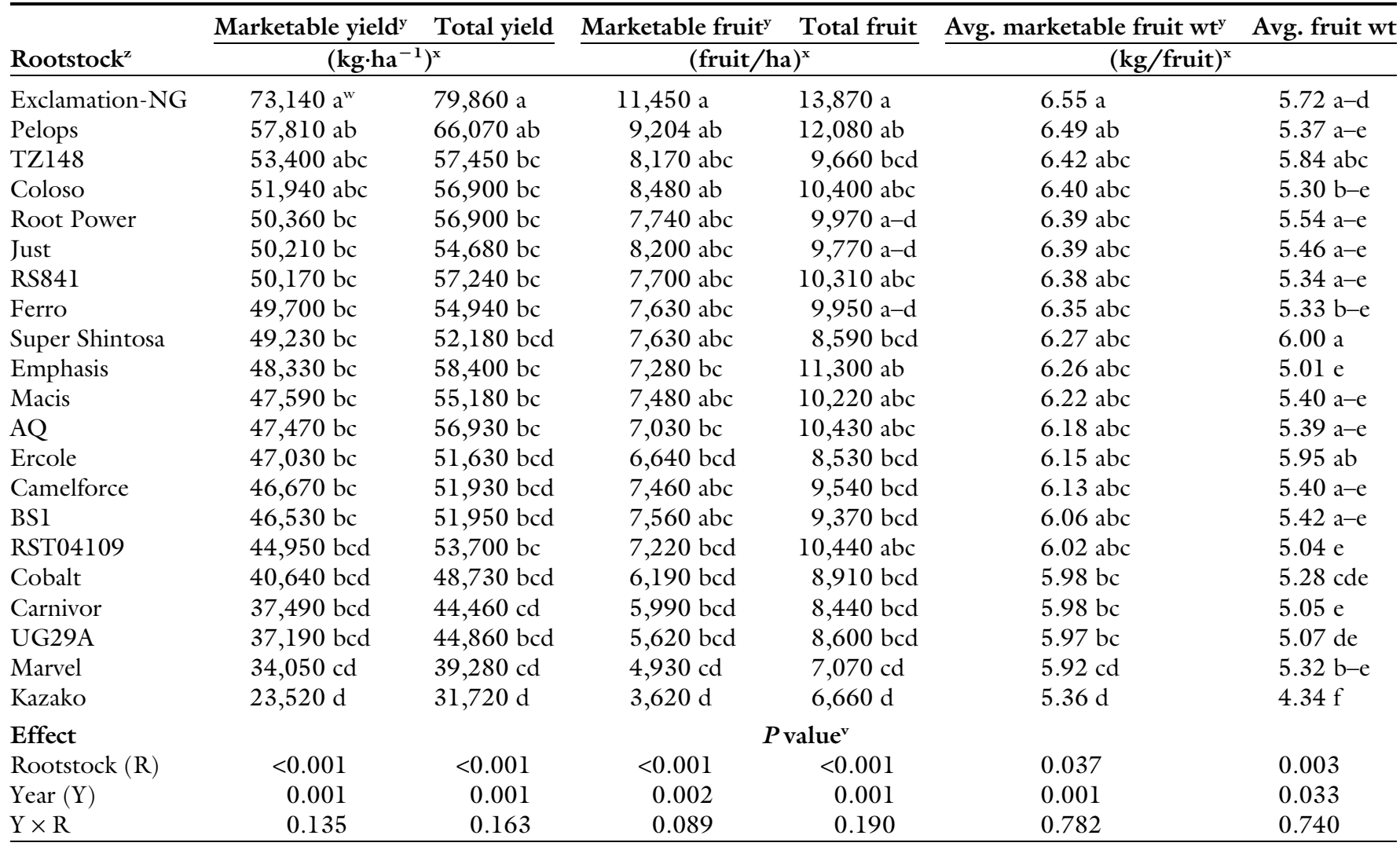

${ }^{z}$ Rootstocks were grafted with 'Exclamation' standard watermelons as the scion. 'Exclamation-NG' represents the nongrafted control.

${ }^{y}$ Marketable yield, marketable fruit number, and average marketable fruit size include fruit weighing $\geq 9 \mathrm{lb}(4.08 \mathrm{~kg})$.

${ }^{\mathrm{x}} \mathrm{l} \mathrm{kg} \cdot \mathrm{ha}^{-1}=0.8922 \mathrm{lb} /$ acre, 1 fruit/ha $=2.4711$ fruit $/$ acre, $1 \mathrm{~kg}=2.2046 \mathrm{lb}$.

${ }^{\mathrm{w}}$ Means separations achieved using the post hoc Tukey's HSD adjustment for multiple comparisons. Values not followed by letters indicate a lack of significance at the $P=0.05$ level.

${ }^{v}$ Probability values reported from analysis of variance output using PROC MIXED in SAS (version 9.4; SAS Institute). Rootstock, year, and year $\times$ rootstock had 20, 1 , and 20 df, respectively. 
Table 5. Comparison of the effect of rootstock selection on yield parameters of 'Extazy' mini watermelon in Kinston, NC, in 2015 and 2016. Ripe fruit were harvested five times and three times in 2015 and 2016, respectively. Fruit were weighed individually and then summed within each year to determine yield parameters.

\begin{tabular}{|c|c|c|c|c|c|c|c|}
\hline \multirow[b]{3}{*}{ Rootstock $^{\mathrm{z}}$} & \multirow[b]{3}{*}{ Marketable yield ${ }^{y}$} & \multicolumn{2}{|c|}{ Total yield } & \multirow[b]{2}{*}{ Marketable fruit $^{\mathrm{y}}$} & \multirow{2}{*}{\multicolumn{2}{|c|}{$\begin{array}{l}\text { Avg. marketable } \\
\text { fruit } w t^{y}\end{array}$}} & \multirow[b]{2}{*}{ Avg. fruit wt } \\
\hline & & 2015 & 2016 & & & & \\
\hline & & \multicolumn{2}{|c|}{$\left(\mathrm{kg} \cdot \mathrm{ha} \mathrm{a}^{-1}\right)^{\mathrm{x}}$} & \multicolumn{2}{|c|}{$(\text { fruit } / \text { ha })^{x}$} & \multicolumn{2}{|c|}{$(\mathrm{kg} / \text { fruit })^{\mathrm{x}}$} \\
\hline Extazy-NG & $73,770 \mathrm{a}^{\mathrm{w}}$ & $63,110 \mathrm{a}$ & $88,670 \mathrm{a}$ & $22,560 \mathrm{a}$ & $25,250 \mathrm{a}$ & 3.22 & 2.99 \\
\hline Coloso & $59,050 \mathrm{ab}$ & $39,220 \mathrm{ab}$ & $80,860 \mathrm{ab}$ & $19,210 \mathrm{ab}$ & $20,120 \mathrm{abc}$ & 2.95 & 2.84 \\
\hline Macis & $57,870 \mathrm{ab}$ & $42,530 \mathrm{ab}$ & $78,320 \mathrm{abc}$ & $18,370 \mathrm{abc}$ & $21,220 \mathrm{ab}$ & 3.04 & 2.76 \\
\hline UG29A & $55,340 \mathrm{abc}$ & $44,850 \mathrm{ab}$ & $68,170 \mathrm{a}-\mathrm{f}$ & $17,750 \mathrm{a}-\mathrm{d}$ & $19,340 \mathrm{abc}$ & 3.06 & 2.88 \\
\hline Camelforce & $53,390 \mathrm{bc}$ & $37,720 \mathrm{ab}$ & $72,450 \mathrm{a}-\mathrm{e}$ & $17,420 \mathrm{a}-\mathrm{d}$ & $18,960 \mathrm{a}-\mathrm{d}$ & 2.91 & 2.76 \\
\hline Carnivor & $53,080 \mathrm{bc}$ & $36,190 \mathrm{ab}$ & $75,380 \mathrm{a}-\mathrm{d}$ & $17,480 \mathrm{a}-\mathrm{d}$ & $20,600 \mathrm{abc}$ & 2.93 & 2.57 \\
\hline BSl & $52,460 \mathrm{bc}$ & $50,560 \mathrm{ab}$ & $58,600 \mathrm{~b}-\mathrm{f}$ & $17,100 \mathrm{a}-\mathrm{d}$ & $19,610 \mathrm{abc}$ & 3.04 & 2.76 \\
\hline Pelops & $52,290 \mathrm{bc}$ & $46,370 \mathrm{ab}$ & $60,850 \mathrm{~b}-\mathrm{f}$ & $16,300 \mathrm{a}-\mathrm{d}$ & $18,270 \mathrm{a}-\mathrm{d}$ & 3.18 & 2.88 \\
\hline $\mathrm{AQ}$ & $50,600 \mathrm{bc}$ & $40,350 \mathrm{ab}$ & $62,550 \mathrm{~b}-\mathrm{f}$ & $18,640 \mathrm{abc}$ & $20,140 \mathrm{abc}$ & 2.68 & 2.52 \\
\hline Ercole & $50,520 \mathrm{bc}$ & $46,750 \mathrm{ab}$ & $55,330 \mathrm{c}-\mathrm{f}$ & $16,630 \mathrm{a}-\mathrm{d}$ & $17,520 \mathrm{bcd}$ & 3.00 & 2.87 \\
\hline Cobalt & $49,530 \mathrm{bc}$ & $39,690 \mathrm{ab}$ & $62,920 \mathrm{~b}-\mathrm{f}$ & $16,710 \mathrm{a}-\mathrm{d}$ & $18,850 \mathrm{a}-\mathrm{d}$ & 2.88 & 2.62 \\
\hline Just & $48,790 \mathrm{bc}$ & $41,040 \mathrm{ab}$ & $58,630 \mathrm{~b}-\mathrm{f}$ & $15,240 \mathrm{bcd}$ & $16,650 \mathrm{bcd}$ & 3.07 & 2.82 \\
\hline RS841 & $48,420 \mathrm{bc}$ & $29,870 \mathrm{ab}$ & $71,550 \mathrm{a}-\mathrm{e}$ & $15,820 \mathrm{a}-\mathrm{d}$ & $18,280 \mathrm{a}-\mathrm{d}$ & 2.87 & 2.51 \\
\hline Ferro & $46,360 \mathrm{bc}$ & $36,540 \mathrm{ab}$ & $58,290 \mathrm{~b}-\mathrm{f}$ & $15,000 \mathrm{bcd}$ & $16,090 \mathrm{bcd}$ & 3.06 & 2.88 \\
\hline TZ148 & $46,190 \mathrm{bc}$ & $31,480 \mathrm{ab}$ & $63,460 \mathrm{~b}-\mathrm{f}$ & $14,460 \mathrm{bcd}$ & $16,000 \mathrm{bcd}$ & 3.08 & 2.87 \\
\hline Root Power & $43,870 \mathrm{bc}$ & $30,300 \mathrm{ab}$ & $59,650 \mathrm{~b}-\mathrm{f}$ & $13,720 \mathrm{bcd}$ & $14,740 \mathrm{bcd}$ & 3.08 & 2.84 \\
\hline Emphasis & $43,500 \mathrm{bc}$ & $39,270 \mathrm{ab}$ & $50,320 \mathrm{def}$ & $13,980 \mathrm{bcd}$ & $15,960 \mathrm{bcd}$ & 3.10 & 2.78 \\
\hline Marvel & $40,660 \mathrm{bc}$ & $27,930 \mathrm{~b}$ & $55,620 \mathrm{c}-\mathrm{f}$ & $12,310 \mathrm{~cd}$ & $13,750 \mathrm{~cd}$ & 3.20 & 2.89 \\
\hline RST04109 & $39,570 \mathrm{bc}$ & $32,900 \mathrm{ab}$ & 50,030 ef & $13,380 \mathrm{bcd}$ & $16,240 \mathrm{bcd}$ & 2.94 & 2.46 \\
\hline Super Shintosa & $38,910 \mathrm{bc}$ & $33,190 \mathrm{ab}$ & $45,610 \mathrm{f}$ & $11,930 \mathrm{~d}$ & $12,630 \mathrm{~d}$ & 3.12 & 2.99 \\
\hline Kazako & $35,480 \mathrm{c}$ & $27,950 \mathrm{~b}$ & 47,960 ef & $12,030 \mathrm{~d}$ & $15,040 \mathrm{bcd}$ & 2.90 & 2.52 \\
\hline Effect & & & & $P$ value ${ }^{\mathrm{v}}$ & & & \\
\hline Rootstock (R) & $<0.001$ & 0.010 & $<0.001$ & $<0.001$ & $<0.001$ & 0.073 & 0.033 \\
\hline Year $(\mathrm{Y})$ & $<0.001$ & - & - & $<0.001$ & $<0.001$ & $<0.001$ & 0.014 \\
\hline $\mathrm{Y} \times \mathrm{R}$ & 0.069 & & 262 & 0.219 & 0.069 & 0.303 & 0.468 \\
\hline
\end{tabular}

${ }^{\text {z } R o o t s t o c k s ~ w e r e ~ g r a f t e d ~ w i t h ~ ' E x t a z y ' ~ m i n i ~ w a t e r m e l o n ~ a s ~ t h e ~ s c i o n . ~ ' E x t a z y-N G ' ~ r e p r e s e n t s ~ t h e ~ n o n g r a f t e d ~ c o n t r o l . ~}$

${ }^{\mathrm{y}}$ Marketable yield, marketable fruit number, and average marketable fruit size include fruit weighing $\geq 3 \mathrm{lb}(1.36 \mathrm{~kg})$.

${ }^{\mathrm{x}} \mathrm{l} \mathrm{kg} \cdot \mathrm{ha}^{-1}=0.8922 \mathrm{lb} /$ acre, $\mathrm{l}$ fruit $/ \mathrm{ha}=2.471 \mathrm{l}$ fruit/acre, $\mathrm{l} \mathrm{kg}=2.2046 \mathrm{lb}$.

${ }^{\text {w } M e a n s ~ s e p a r a t i o n s ~ a c h i e v e d ~ u s i n g ~ t h e ~ p o s t ~ h o c ~ T u k e y ' s ~ H S D ~ a d j u s t m e n t ~ f o r ~ m u l t i p l e ~ c o m p a r i s o n s . ~ V a l u e s ~ n o t ~ f o l l o w e d ~ b y ~ l e t t e r s ~ i n d i c a t e ~ a ~ l a c k ~ o f ~ s i g n i f i c a n c e ~ a t ~ t h e ~} P=0.05$ level.

${ }^{\mathrm{v}}$ Probability values reported from analysis of variance output using PROC MIXED in SAS (version 9.4; SAS Institute). Rootstock, year, and year $\times$ rootstock had 20,1 , and 20 df, respectively.

percentage of marketable fruit). A significant difference between the percentages of 60-count fruit was only observed between 'AQ' and 'BSI' rootstocks, which accounted for $26 \%$ and $51 \%$ of the total yield, respectively (Table 6). No differences were observed in 45-count, 36-count, and 30-count categories.

In the 'Extazy' mini watermelon study, nongrafted plants produced the highest marketable yield, total yield, marketable fruit number, and total fruit number (Table 5). 'Extazy' grafted onto 'Coloso', 'Macis', and 'UG29A' rootstocks produced similar marketable yields to nongrafted 'Extazy'. The next highest marketable yield was 'Camelforce' rootstock, which produced $72 \%$ of the marketable yield of nongrafted 'Extazy'. Similar to standard size 'Exclamation' watermelon results, 'Kazako' rootstock produced the lowest marketable yields ( $48 \%$ of nongrafted 'Extazy'). Marketable and total fruit numbers followed similar patterns with highest fruit numbers produced by nongrafted 'Extazy', and lowest marketable and total fruit numbers produced by 'Kazako' and 'Super Shintosa' rootstocks, respectively. However, rootstock had no significant effect on average marketable fruit size $(P=0.073)$; and, despite a significant effect of rootstock on average fruit size $(P=$ 0.033 ), Tukey's HSD multiple comparisons adjustment detected no significant differences among rootstock treatments.

Although studies were designed to compare the performance of individual rootstocks, notable trends were observed among marketable watermelon yield when grafting to different rootstock species.
Highest marketable yields in the 'Exclamation' study included the nongrafted control, two bottle gourd rootstocks ('Coloso' and 'Pelops'), and an ISH rootstock ('TZ148') (Table 4). In the 'Extazy' study, highest marketable yields included the nongrafted control and three bottle gourd species ['Coloso', 'Macis', and 'UG29A' (Table 5)]. Thus, the only treatments to consistently produce the highest marketable yields across both 'Exclamation' and 'Extazy' studies were the nongrafted controls and 'Coloso' rootstock. Neither of the summer squash rootstocks ('AQ' and 'BSI') nor the giant pumpkin rootstock ('Root Power') produced marketable yields similar to nongrafted treatments when grafting with 'Exclamation' or 'Extazy'. Although an ISH rootstock ('TZl48') produced a similar marketable yield to 
Table 6. Comparison of the effect of rootstock selection on fruit size distribution (by weight) of 'Exclamation' standard watermelon at Kinston, NC, in 2015 and 2016. Ripe fruit were harvested four times each season at weekly intervals, weighed individually, and then summed within each year, according to bin counts.

\begin{tabular}{|c|c|c|c|c|c|c|}
\hline \multirow[b]{3}{*}{ Rootstock $^{\mathrm{y}}$} & \multicolumn{6}{|c|}{ Bin count ${ }^{\mathrm{z}}$} \\
\hline & Cull & 60 -count & 45-count & 36-count & 30 -count & Marketable $^{\mathrm{x}}$ \\
\hline & \multicolumn{6}{|c|}{ (\% of total yield) } \\
\hline Pelops & $13 \mathrm{~b}$ & $40 \mathrm{ab}$ & 33 & 11 & 4 & $87 \mathrm{a}$ \\
\hline TZ148 & $7 \mathrm{~b}$ & $34 \mathrm{ab}$ & 45 & 12 & 1 & $93 a$ \\
\hline Coloso & $8 \mathrm{~b}$ & $50 \mathrm{ab}$ & 29 & 11 & 1 & $92 \mathrm{a}$ \\
\hline RS841 & $14 \mathrm{~b}$ & $41 \mathrm{ab}$ & 29 & 13 & 2 & $86 a$ \\
\hline Ferro & $12 \mathrm{~b}$ & $38 \mathrm{ab}$ & 32 & 17 & 1 & $88 \mathrm{a}$ \\
\hline Super Shintosa & $6 \mathrm{~b}$ & $38 \mathrm{ab}$ & 35 & 18 & 3 & $94 \mathrm{a}$ \\
\hline Emphasis & $19 \mathrm{ab}$ & $35 \mathrm{ab}$ & 34 & 12 & 0 & $81 \mathrm{ab}$ \\
\hline Macis & $14 \mathrm{~b}$ & $33 \mathrm{ab}$ & 41 & 8 & 4 & $87 \mathrm{a}$ \\
\hline RST04109 & $18 \mathrm{ab}$ & $42 \mathrm{ab}$ & 28 & 11 & 1 & $82 \mathrm{ab}$ \\
\hline Cobalt & $19 \mathrm{ab}$ & $39 a b$ & 27 & 14 & 1 & $81 \mathrm{ab}$ \\
\hline Carnivor & $17 \mathrm{ab}$ & $43 \mathrm{ab}$ & 25 & 13 & 1 & $83 \mathrm{ab}$ \\
\hline UG29A & $19 \mathrm{ab}$ & $30 \mathrm{ab}$ & 31 & 18 & 3 & $81 \mathrm{ab}$ \\
\hline Marvel & $15 \mathrm{~b}$ & $34 \mathrm{ab}$ & 32 & 13 & 5 & $85 \mathrm{a}$ \\
\hline Kazako & $34 \mathrm{a}$ & $48 \mathrm{ab}$ & 16 & 1 & 0 & $66 \mathrm{~b}$ \\
\hline Effect & & & & $\operatorname{lue}^{\mathrm{v}}$ & & \\
\hline Rootstock (R) & 0.002 & 0.010 & 0.448 & 0.589 & 0.424 & 0.002 \\
\hline Year (Y) & 0.010 & $<0.001$ & $<0.001$ & $<0.001$ & 0.018 & 0.010 \\
\hline $\mathrm{Y} \times \mathrm{R}$ & 0.112 & 0.065 & 0.598 & 0.660 & 0.448 & 0.112 \\
\hline
\end{tabular}

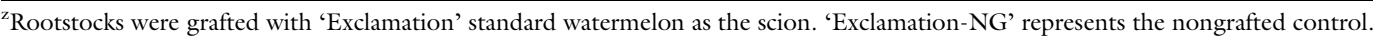

${ }^{\mathrm{y}} \mathrm{Bin}$ counts refers to the number of watermelons required to fill an 800 -lb bin and are defined by National Watermelon Research and Development Group standards: culls $<9$ lb, 60 -count $\geq 9$ to $13.5 \mathrm{lb}, 45$-count $>13.5$ to $17.5 \mathrm{lb}, 36$-count $>17.5$ to $21.5 \mathrm{lb}$, and 30 -count $>21.5 \mathrm{lb} ; 1 \mathrm{lb}=0.4536 \mathrm{~kg}$.

${ }^{\mathrm{x}}$ Marketable yield only includes fruit weighing $\geq 9 \mathrm{lb}$.

weans separations achieved using the post hoc Tukey's HSD adjustment for multiple comparisons. Values not followed by letters indicate a lack of significance at the $P=0.05$ level.

"Probability values reported from analysis of variance output using PROC MIXED in SAS (version 9.4; SAS Institute). Rootstock, year, and year $\times$ rootstock had 20,1 , and 20 df, respectively.

nongrafted 'Exclamation', no ISH rootstock produced marketable yields similar to nongrafted 'Extazy'. 'Kazako' ISH rootstock produced among the lowest marketable yield, total yield, marketable fruit number, and total fruit number in both studies.

WATERMELON FRUIT QUALITY. Analysis of fruit quality included watermelon flesh firmness (Newtons), acidity $(\mathrm{pH}), \mathrm{SSC}$, and lycopene content (micrograms per gram lycopene-fresh tissue). No interaction of year with rootstock was observed for any dependent variable; thus, means separation was conducted using the combined means across both years in each experiment (Tables 7 and 8). Rootstock selection had a significant effect on flesh firmness in both 'Exclamation' and
'Extazy' experiments $(P<0.001$ and 0.001 , respectively); and fruit from the nongrafted plants in both studies had the lowest flesh firmness. A significant effect of rootstock on fruit acidity existed in the 'Exclamation' study $(P=0.041)$, but means separation with post hoc Tukey's HSD multiple comparisons adjustment only detected a difference between rootstocks with the lowest and highest fruit acidity- 'Pelops' (pH 5.82) and 'Cobalt' (pH 5.51), respectively; and no statistical difference in acidity was observed among all other treatments (Table $7)$. By contrast, acidity was unaffected by rootstock selection $(P=$ 0.591 ) in the 'Extazy' study (Table 8 ). Rootstock had no effect on SSC or lycopene content in 'Exclamation' or 'Extazy' studies.

\section{Discussion}

Although watermelon grafting may provide benefits in the presence of biotic and abiotic stressors, the present study demonstrates that grafted plants do not increase yields nor increase fruit quality when production systems are optimized and fields are absent of environmental stress. Marketable yield, total yield, marketable fruit number, and total fruit number were highest in nongrafted 'Exclamation' and 'Extazy'. Our findings demonstrated that several bottle gourd rootstocks ('Emphasis', 'Coloso', and 'Pelops') produced high marketable yields, comparable to nongrafted controls; however, all but one ISH rootstock ('TZ148') had reduced marketable yields. The present findings agree 
Table 7. Results of postharvest analyses to determine the effect of rootstock selection on 'Exclamation' watermelon fruit quality using two-fruit samples from each of two harvests from field trials in Kinston, NC, repeated in 2015 and 2016. Immediately following harvest, flesh firmness was measured by cutting watermelon longitudinally, from stem to blossom, and then pressing a force gauge into five positions on each fruit: top, bottom, stem, blossom, and heart. Flesh firmness was recorded as peak resistance and averaged across the five positions, two-fruit samples, harvests, and years. Watermelon acidity, soluble solids concentration (SSC), and lycopene content were determined using a 100-g (3.53 oz) sample scooped from center of each watermelon then bagged individually, placed on ice, and analyzed in the laboratory. Watermelon acidity, SSC, and lycopene content were averaged across two-fruit samples, harvests, and years.

\begin{tabular}{|c|c|c|c|c|}
\hline \multirow[b]{2}{*}{ Rootstock $^{\mathrm{z}}$} & \multicolumn{4}{|c|}{ Watermelon quality } \\
\hline & 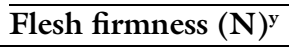 & Acidity $(\mathrm{pH})$ & SSC (\%) & Lycopene $\left(\mu \mathrm{g} \cdot \mathrm{g}^{-1}\right)^{\mathrm{y}}$ \\
\hline Kazako & $1.10 \mathrm{a}^{\mathrm{x}}$ & $5.73 \mathrm{ab}$ & 12.2 & 69 \\
\hline Marvel & $1.09 \mathrm{a}$ & $5.59 \mathrm{ab}$ & 11.2 & 61 \\
\hline $\mathrm{AQ}$ & $1.06 \mathrm{ab}$ & $5.61 \mathrm{ab}$ & 12.1 & 68 \\
\hline Ercole & $1.04 \mathrm{ab}$ & $5.67 \mathrm{ab}$ & 11.6 & 68 \\
\hline Root Power & $1.04 \mathrm{abc}$ & $5.65 \mathrm{ab}$ & 12.1 & 67 \\
\hline Carnivor & $1.03 \mathrm{abc}$ & $5.61 \mathrm{ab}$ & 12.3 & 69 \\
\hline Cobalt & $1.03 \mathrm{abc}$ & $5.51 \mathrm{~b}$ & 11.6 & 64 \\
\hline Ferro & $1.03 \mathrm{abc}$ & $5.72 \mathrm{ab}$ & 12.4 & 69 \\
\hline BSI & $1.02 \mathrm{abc}$ & $5.63 \mathrm{ab}$ & 11.7 & 63 \\
\hline Camelforce & $1.02 \mathrm{abc}$ & $5.69 \mathrm{ab}$ & 11.8 & 67 \\
\hline RS841 & $1.01 \mathrm{abc}$ & $5.58 \mathrm{ab}$ & 11.7 & 66 \\
\hline Emphasis & $1.01 \mathrm{abc}$ & $5.68 \mathrm{ab}$ & 11.4 & 62 \\
\hline UG29A & $1.01 \mathrm{abc}$ & $5.67 \mathrm{ab}$ & 12.4 & 64 \\
\hline Just & $1.00 \mathrm{abc}$ & $5.60 \mathrm{ab}$ & 11.1 & 66 \\
\hline RST04109 & $0.99 \mathrm{a}-\mathrm{d}$ & $5.63 \mathrm{ab}$ & 12.0 & 66 \\
\hline Super Shintosa & $0.98 \mathrm{a}-\mathrm{d}$ & $5.67 \mathrm{ab}$ & 11.4 & 63 \\
\hline TZ148 & $0.98 \mathrm{a}-\mathrm{d}$ & $5.67 \mathrm{ab}$ & 12.0 & 68 \\
\hline Pelops & $0.90 \mathrm{bcd}$ & $5.83 \mathrm{a}$ & 12.1 & 67 \\
\hline Macis & $0.90 \mathrm{bcd}$ & $5.68 \mathrm{ab}$ & 11.8 & 65 \\
\hline Coloso & $0.88 \mathrm{~cd}$ & $5.75 \mathrm{ab}$ & 12.0 & 63 \\
\hline Exclamation-NG & $0.83 \mathrm{~d}$ & $5.77 \mathrm{ab}$ & 11.7 & 61 \\
\hline Effect & \multicolumn{4}{|c|}{$P$ value ${ }^{\mathrm{w}}$} \\
\hline Rootstock (R) & $<0.001$ & 0.041 & 0.054 & 0.241 \\
\hline $\operatorname{Year}(\mathrm{Y})$ & 0.004 & 0.741 & 0.004 & 0.023 \\
\hline $\mathrm{Y} \times \mathrm{R}$ & 0.557 & 0.915 & 0.084 & 0.092 \\
\hline
\end{tabular}

${ }^{\text {z}}$ Rootstocks were grafted with 'Exclamation' standard watermelon as the scion. 'Exclamation-NG' represents the nongrafted control.

${ }^{\mathrm{y}} 1 \mathrm{~N}=0.2248 \mathrm{lbf}, 1 \mu \mathrm{g} \cdot \mathrm{g}^{-1}=1 \mathrm{ppm}$.

${ }^{\mathrm{x}}$ Means separations achieved using the post hoc Tukey's HSD adjustment for multiple comparisons. Values not followed by letters indicate a lack of significance at the $P=0.05$ level

wProbability values reported from analysis of variance output using PROC MIXED in SAS (version 9.4; SAS Institute). Rootstock, year, and year $\times$ rootstock had 20,1 , and $20 \mathrm{df}$, respectively.

with several previous studies where grafted plants yielded similarly or worse than nongrafted plants (Bertucci et al., 2017; Kokalis-Burelle et al., 2016; Miller et al., 2013), but run contrary to others where yield increases were observed as a result of grafting (Miguel et al., 2004; Mohamed et al., 2012; Turhan et al., 2012). When comparing marketable yield based on rootstock species, our results agreed with previous research, which reported highest yields when grafting to bottle gourd rootstocks and decreased yields when grafting to ISH rootstocks (Yetisir et al., 2003).
An increase in flesh firmness was associated with grafting, which was also reported in other studies (Davis and Perkins-Veazie, 2005; Kyriacou and Soteriou, 2015; Liu et al., 2017). Except for two rootstocks grafted with 'Exclamation' ('Pelops' and 'Cobalt'), watermelon acidity was unaffected by grafting. And no differences were observed in SSC or the lycopene content for either watermelon type. A review article summarizes the effects of grafting on watermelon fruit quality characteristics, and it is concluded that rootstock-scion combinations may have differing effects on flesh firmness and SSC (Davis et al., 2008a). Specifically, watermelon grafting has been associated with reduced flesh firmness and decreased SSC (Lee and Oda, 2003), but one study found increased SSC, flesh firmness, and lycopene content as a result of grafting (Davis and Perkins-Veazie, 2005), whereas another study observed no difference in SSC between grafted and nongrafted watermelon (Miguel et al., 2004). Thus, variability exists in the literature regarding the effects of grafting on watermelon fruit quality. The results of the present study suggest that grafting 'Exclamation' and 'Extazy' to the selected rootstocks increases watermelon flesh firmness, but does not affect SSC or lycopene content of watermelon in a fumigated plasticulture production system.

Environmental conditions and production systems play a role in the performance of grafted plants, and some variability is to be expected when trials are conducted across differing geographies. Furthermore, specific rootstock-scion combinations may perform differently depending on environmental conditions. However, the present study evaluated two watermelon types (standard and mini-sized watermelon) with a diverse selection of 20 rootstocks. Authors observed that watermelon grafting with the studied rootstock-scion combinations did not improve yield and that only minimal fruit quality benefits occurred in fumigated North Carolina plasticulture production systems. This disparity between the present study and previous studies, which have reported an increase in yield as a result of grafting (Miguel et al., 2004; Mohamed et al., 2012; Turhan et al., 2012), is likely due to the fumigation and disease-free conditions of this study. Mohamed et al. (2012) evaluated grafted and nongrafted watermelons in fusarium wilt-infested fields and concluded that differences in yield were primarily explained by differences in the survival of plants: $67 \%$ among nongrafted plants and $83 \%$ to $100 \%$ among grafted plants. Thus, grafting watermelon offers utility for resistance to fusarium wilt or verticillium wilt (Verticillium dabliae), two diseases incited by soilborne pathogens (Guan et al., 2012; Keinath and Hassell, 2013; Kleinhenz, 2015). Two 
Table 8. Results of postharvest analyses to determine the effect of rootstock selection on 'Extazy' mini watermelon fruit quality using two-fruit samples from the initial two harvests from field trials in Kinston, NC, repeated in 2015 and 2016. Immediately following harvest, flesh firmness was measured by cutting watermelon longitudinally, from stem to blossom, and then pressing a force gauge into five positions on each fruit: top, bottom, stem, blossom, and heart. Flesh firmness was recorded as peak resistance and averaged across the five positions, two-fruit samples, and harvests. Watermelon acidity, soluble solids concentration (SSC), and lycopene content were determined using a 100-g (3.53 oz) sample scooped from the center of each watermelon, bagged individually, placed on ice, and analyzed in the laboratory.

\begin{tabular}{|c|c|c|c|c|}
\hline \multirow[b]{2}{*}{ Rootstock $^{\mathrm{z}}$} & \multicolumn{4}{|c|}{ Mini watermelon quality } \\
\hline & $\overline{\text { Flesh firmness }(\mathrm{N})^{\mathrm{y}}}$ & Acidity $(\mathrm{pH})$ & SSC (\%) & Lycopene $\left(\mu g \cdot g^{-1}\right)^{y}$ \\
\hline Cobalt & $1.28 \mathrm{a}^{\mathrm{x}}$ & 5.74 & 10.4 & 102 \\
\hline Camelforce & $1.26 \mathrm{a}$ & 5.66 & 10.5 & 95 \\
\hline RST04109 & $1.25 \mathrm{a}$ & 5.72 & 10.3 & 92 \\
\hline UG29A & $1.22 \mathrm{ab}$ & 5.70 & 10.4 & 94 \\
\hline Just & $1.22 \mathrm{ab}$ & 5.80 & 10.7 & 98 \\
\hline Ercole & $1.20 \mathrm{ab}$ & 5.77 & 11.0 & 104 \\
\hline Marvel & $1.19 \mathrm{ab}$ & 5.80 & 10.6 & 98 \\
\hline TZ148 & $1.19 \mathrm{ab}$ & 5.74 & 10.4 & 90 \\
\hline Carnivor & $1.18 \mathrm{ab}$ & 5.68 & 10.3 & 91 \\
\hline Super Shintosa & $1.17 \mathrm{ab}$ & 5.66 & 9.8 & 98 \\
\hline BS1 & $1.17 \mathrm{ab}$ & 5.73 & 10.1 & 99 \\
\hline AQ & $1.16 \mathrm{ab}$ & 5.72 & 10.3 & 92 \\
\hline Ferro & $1.15 \mathrm{ab}$ & 5.93 & 10.6 & 105 \\
\hline Kazako & $1.14 \mathrm{ab}$ & 5.81 & 10.6 & 95 \\
\hline Root Power & $1.14 \mathrm{ab}$ & 5.65 & 10.1 & 92 \\
\hline Coloso & $1.10 \mathrm{ab}$ & 5.82 & 10.5 & 92 \\
\hline Emphasis & $1.09 \mathrm{ab}$ & 5.81 & 10.8 & 90 \\
\hline Macis & $1.06 \mathrm{ab}$ & 5.95 & 10.9 & 94 \\
\hline RS841 & $1.04 \mathrm{ab}$ & 5.72 & 10.3 & 100 \\
\hline Pelops & $1.04 \mathrm{ab}$ & 5.92 & 11.5 & 87 \\
\hline Extazy-NG & $0.97 \mathrm{~b}$ & 5.79 & 10.8 & 83 \\
\hline Effect & \multicolumn{4}{|c|}{$P$ value ${ }^{\mathrm{w}}$} \\
\hline Rootstock (R) & 0.001 & 0.591 & 0.070 & 0.213 \\
\hline Year (Y) & 0.055 & 0.003 & 0.001 & 0.011 \\
\hline $\mathrm{Y} \times \mathrm{R}$ & 0.307 & 0.389 & 0.301 & 0.681 \\
\hline
\end{tabular}

${ }^{z}$ Rootstocks were grafted with 'Extazy' mini watermelon as the scion. 'Extazy-NG' represents the nongrafted control.

${ }^{y} 1 \mathrm{~N}=0.2248 \mathrm{lbf}, \mathrm{l} \mu \mathrm{g} \cdot \mathrm{g}^{-1}=1 \mathrm{ppm}$

${ }^{\mathrm{x}}$ Means separations achieved using the post hoc Tukey's HSD adjustment for multiple comparisons. Values not followed by letters indicate a lack of significance at the $P=0.05$ level.

"Probability values reported from analysis of variance output using PROC MIXED in SAS (version 9.4; SAS Institute). Rootstock, year, and year $\times$ rootstock had 20,1 , and $20 \mathrm{df}$, respectively.

economic analyses indicate that watermelon grafting would be profitable in the United States, particularly when fields are infested with fusarium wilt or verticillium wilt (Taylor et al., 2008; Wimer et al., 2015). Therefore, it would be most beneficial to consider disease resistance characteristics of a rootstock and implement grafting only in situations where soilborne pathogens are anticipated to interfere with watermelon production. Our study highlights a selection of rootstocks that offer highest yield in the absence of soilborne disease or environmental stresses, and the data presented here may be used to compliment decisions for disease management.

\section{Literature cited}

Bertucci, M.B., K. Jennings, D. Monks, D. Jordan, F. Louws, J.R. Schultheis, S. Smith, N.T. Basinger, and M. Waldschmidt. 2017. Influence of grafting on the critical period for weed control in grafted watermelon. HortScience 52:S74 (abstr.).

Colla, G., Y. Rouphael, C. Mirabelli, and M. Cardarelli. 2011. Nitrogen-use efficiency traits of mini-watermelon in response to grafting and nitrogen-fertilization doses. J. Plant Nutr. Soil Sci. 174(6): 933-941.
Coolong, T. 2015. Trial report: Seedless watermelon variety evaluation. 5 May 2018. <http://blog.extension.uga.edu/ colquittag/files/2016/01/2015-UGATifton-Watermelon-Variety-TrialResults.pdf>.

Daley, S. and R. Hassell. 2014. Fatty alcohol application to control meristematic regrowth in bottle gourd and interspecific hybrid squash rootstocks used for grafting watermelon. HortScience 49:260-264.

Davis, A.R., W.W. Fish, and P. PerkinsVeazie. 2003. A rapid hexane-free method for analyzing lycopene content in watermelon. J. Food Sci. 68(1):328-332.

Davis, A.R. and P. Perkins-Veazie. 2005. Rootstock effects on plant vigor and watermelon fruit quality. Cucurbit Genet. Coop. Rpt. 28:39-42.

Davis, A.R., P. Perkins-Veazie, R. Hassell, A. Levi, S.R. King, and X. Zhang. 2008a. Grafting effects on vegetable quality. HortScience 43:1670.

Davis, A.R., P. Perkins-Veazie, Y. Sakata, S. Lopez-Galarza, J.V. Maroto, S. Lee, Y. Huh, Z. Sun, A. Miguel, S.R. King, R. Cohen, and J. Lee. 2008b. Cucurbit grafting. Crit. Rev. Plant Sci. 27:50-74.

Dittmar, P.J., D.W. Monks, and J.R. Schultheis. 2010. Use of commercially available pollenizers for optimizing triploid watermelon production. HortScience 45:541-545.

Easlon, H.M. and A.J. Bloom. 2014. Easy leaf area: Automated digital image analysis for rapid and accurate measurement of leaf area. Appl. Plant Sci. 2(7):1400033.

Galinato, S., C. Miles, and J. Wimer. 2016. Non-grafted and grafted seedless watermelon transplants: Comparative economic feasibility analysis. Washington State Univ. Ext. Publ. TB08.

Guan, W., X. Zhao, R. Hassell, and J. Thies. 2012. Defense mechanisms involved in disease resistance of grafted vegetables. HortScience 47:164-170.

Hassell, R.L., F. Memmott, and D.G. Liere. 2008. Grafting methods for watermelon production. HortScience 43: 1677-1679.

Keinath, A.P. and R.L. Hassell. 2013. Control of fusarium wilt of watermelon by grafting onto bottlegourd or interspecific hybrid squash despite colonization of the rootstocks by Fusarium oxysporum. Plant Dis. 98:255-266.

Kleinhenz, M.D. 2015. Description of commercial cucurbit rootstocks. Common cucurbit diseases and pests and susceptibility characteristics. 5 Feb. 2015. <http://www.vegetablegrafting.org/ wp/wp-content/uploads/2015/02/ 
usda-scri-cucurbit-rootstock-table-feb15.pdf>.

Kokalis-Burelle, N., D.M. Butler, J.C. Hong, M.G. Bausher, G. McCollum, and E.N. Rosskopf. 2016. Grafting and paladin pic-21 for nematode and weed management in vegetable production. J. Nematol. 48(4):231-240.

Kubota, C., M.A. McClure, N. KokalisBurelle, M.G. Bausher, and E.N. Rosskopf. 2008. Vegetable grafting: History, use, and current technology status in north America. HortScience 43:1664-1669.

Kumar, P., Y. Rouphael, M. Cardarelli, and G. Colla. 2017. Vegetable grafting as a tool to improve drought resistance and water use efficiency. Front. Plant Sci. 8:1130.

Kyriacou, M.C. and G. Soteriou. 2015. Quality and postharvest performance of watermelon fruit in response to grafting on interspecific cucurbit rootstocks. J. Food Qual. 38(1):21-29.

Lee, J. and M. Oda. 2003. Grafting of herbaceous vegetable and ornamental crops. Hort. Rev. 28:61-124.

Liu, Q., X. Zhao, J.K. Brecht, C.A. Sims, T. Sanchez, and N.S. Dufault. 2017. Fruit quality of seedless watermelon grafted onto squash rootstocks under different production systems. J. Sci. Food Agr. 97(14):4704-4711.

Louws, F.J., C.L. Rivard, and C. Kubota. 2010. Grafting fruiting vegetables to manage soilborne pathogens, foliar pathogens, arthropods and weeds. Scientia Hort. 127(2):127-146.
Maynard, D.M. 1989. Triploid watermelon seed orientation affects seedcoat adherence on emerged cotyledons. HortScience 24:603-604.

Miguel, A., J. Maroto, A. Bautista, C. Baixauli, V. Cebolla, B. Pascual, S. Lopez, and J. Guardiola. 2004. The grafting of triploid watermelon is an advantageous alternative to soil fumigation by methyl bromide for control of fusarium wilt. Scientia Hort. 103(1):9-17.

Miller, G., A. Khalilian, J.W. Adelberg, H.J. Farahani, R.L. Hassell, and C.E. Wells. 2013. Grafted watermelon root length density and distribution under different soil moisture treatments. HortScience 48:1021-1026.

Mohamed, F.H., K. El-Hamed, M.W.M. Elwan, and M.N.E. Hussien. 2012. Impact of grafting on watermelon growth, fruit yield and quality. Veg. Crops Res. Bul. 76:99-118.

Moreno, B., C. Jacob, M. Rosales, C. Krarup, and S. Contreras. 2016. Yield and quality of grafted watermelon grown in a field naturally infested with fusarium wilt. HortTechnology 26:453-459.

Rouphael, Y., M. Cardarelli, G. Colla, and E. Rea. 2008. Yield, mineral composition, water relations, and water use efficiency of grafted mini-watermelon plants under deficit irrigation. HortScience 43:730 736.

Sakata, Y., T. Ohara, and M. Sugiyama. 2007. The history and present state of the grafting of cucurbitaceous vegetables in Japan. Acta Hort. 731:159-170.

Tateishi, K. 1927. Grafting watermelon onto pumpkin. J. Jpn. Hort. (NihonEngei Zasshi) 39:5-8.

Taylor, M., B. Bruton, W. Fish, and W. Roberts. 2008. Cost benefit analyses of using grafted watermelon transplants for fusarium wilt disease control. Acta Hort. 782:343-350.

Turhan, A., N. Ozmen, H. Kuscu, M.S. Serbeci, and V. Seniz. 2012. Influence of rootstocks on yield and fruit characteristics and quality of watermelon. Hort. Environ. Biotechnol. 53(4):336-341.

Vinson, E., F. Woods, J. Kemble, P. PerkinsVeazie, A. Davis, and J. Kessler. 2010. Use of external indicators to predict maturity of mini-watermelon fruit. HortScience 45:1034-1037.

Wimer, J., D. Inglis, and C. Miles. 2015. Evaluating grafted watermelon for verticillium wilt severity, yield, and fruit quality in Washington state. HortScience 50:1332-1337.

Yetisir, H., N. Sari, and S. Yucel. 2003. Rootstock resistance to fusarium wilt and effect on watermelon fruit yield and quality. Phytoparasitica 31(2):163-169.

Zagheni, E. 2003. Grafting replaces methyl bromide. Appropriate Technol. 30(4):10-11. 